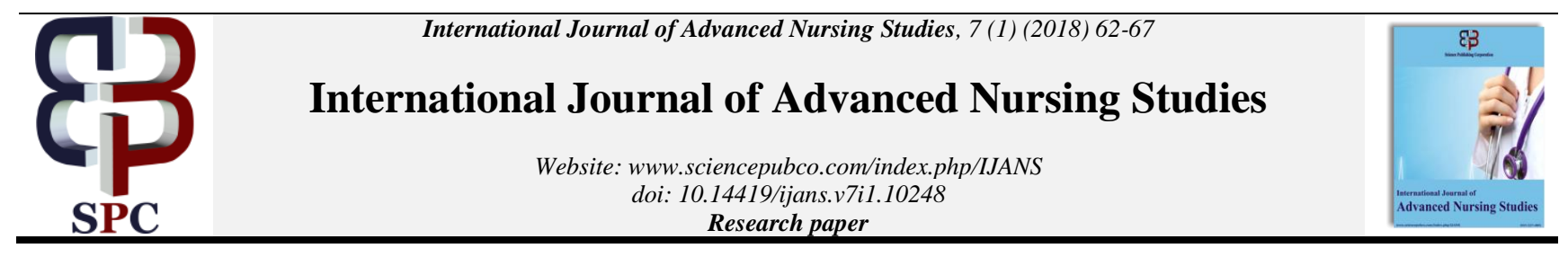

\title{
The effect of intervention program on nursing students attitudes regarding ageism
}

\author{
Lamia A. Awad ${ }^{1}$ *, Zainab Hassan Hassan Osman ${ }^{2}$, Safaa Abdlazem Osman ${ }^{3}$ \\ ${ }^{1}$ Assistant professor of Community Health Nursing, Faculty of Nursing, Al-Mansoura University, Egypt \\ ${ }^{2}$ Lecturer of Psychiatric Mental Health Nursing, Faculty of Nursing, Fayoum University, Egypt \\ ${ }^{3}$ Lecturer of Psychiatric Mental Health Nursing, Faculty of Nursing, Suez Canal University, Egypt \\ *Corresponding author E-mail: laawadh@uod.edu.sa
}

\begin{abstract}
Background: Nursing positions for older students can affect the quality of care provided to them. The values, perceptions, and beliefs of health care nurses towards the elderly are considered among the underlying causes of prejudice against the elderly.

Objective: This study aimed to study the effect of intervention program on the attitudes of students towards Ageism.

Methodology: The study was conducted at the Faculty of Nursing - Mansoura University using semi-experimental design with prior evaluation of the other to conduct this study. A total number of 110 nursing students attending Mansoura University were included in the study. A self-administered questionnaire and the educational background on aging and care of the elderly using the attitude of Kogan towards the elderly scale were used. A structured educational intervention with gerontology content for students was designed and implemented to raise students ' knowledge, and improve their attitudes toward the ageism. The study was conducted from February 2016 to May 2016.

Results: There was a statistically significant difference in total score of negative attitude scale items before and after implementation of gerontology nursing course.

Conclusion \& recommendation: The educational intervention with gerontology content is valuable in humanizing nursing students' negative attitude toward the ageism. Nurse educators strengthen gerontological content in the nursing curriculum and provide tailored nursing education to reduce ageism among professional nurses as well as dissemination of educational intervention with gerontology content to other nursing students in all specialties in Egypt for further confirmation of the findings.
\end{abstract}

Keywords: Ageism; Attitudes; Course; Gerontology; Nursing; Student.

\section{Introduction}

Aging is a natural part of the entire human society, it is not indicating biological changes only, but also it mirrors cultural and societal convention about it (Libertini \& Ferrara, 2016). For the elderly population, one of the main issues facing health care systems; it is a fact that admits that with age, the probability of developing health problems and chronic diseases will increase, demand for healthcare resources will rise, according to World Health Organization (2016), between 2000 and 2050; the percentage of the world population over 60 years will double from about $11 \%$ to $22 \%$ globally, with the vast majority of older people living in low and middle-income countries.

Discrimination against older persons is a common form of discrimination that includes negative views and stereotypes about the age of the elderly. This type of discrimination can have a significant negative impact on the welfare and well-being of older people (Liu et al., 2015). Nurses should therefore identify and eliminate personal attitudes of discrimination against older people by understanding the reality of aging and identifying common misconceptions by communicating with individuals, families and society and helping disseminate accurate information about the needs and characteristics of the elderly population through the media and through acting as role models for staff to advocate for the rights of elders as well as changes associated with aging and misconceptions of aging (Coffey \& Whitehead, 2015).

Negative attitudes and discrimination against elderly are obstacles to provide high-quality care for the rapidly growing older population aged 65 years and older which deprive older of human dignity and prevent social participation. These negative experiences decrease self-esteem and instill feelings of shame and guilt that prevent the older population from having effective interpersonal relationships, which would then lead to withdrawal and social isolation as a result from the different prejudices, manners and behavior towards human being just because of their age (Swift et al., 2017).

Nurses must provide support to older people; these may promote positive attitudes about themselves and the providers and vice versa. When older people are respected by younger individuals, they feel a sense of belonging and acceptance. With positive attitudes, a positive relationship is created between nurses and the elderly where nurses provide one-on-one services to elderly individuals in many areas, from preventive health care to palliative care (Bravo, 2017). In addition, nursing working with the shift system, long and tiring hours, and an insufficient number of staff to work with cases that require special attention, education, detailed inspection, and protection have to develop negative attitudes. Because they are likely to meet sickly older adults in acute care facilities, their perceptions are often based on unwell and 
fragile older adults and limited to develop negative attitudes toward older patients (Schlein, 2016).

One of the most important nursing knowledge is the influence factor and attitudes towards older education. Therefore, it is important to look at the attitude of nurses towards elder care to better focus on the nursing education program of gerontology towards the best possible care of older people (Demir et al., 2016). This is more important because older people do not care about the geriatric ward but on public wards and some nurses have left feeling forced to work in an area that is considered unattractive (Meiner, 2015).

The significance of study:

According to the Central Agency for Public Mobilization and Statistics (2010), In Egypt, the percentage of elder people in 1996 was around 6\%, while the expected percentage will be $10.9 \%$ in 2026 respectively. That's why the nurses must be prepared to meet the challenges of caring for this rapidly increasing segment of the population and be aware of the characteristics of the aging population, special concerns and issues of importance to those individuals who will most likely dominate nursing practice worldwide. More than once this reflects the importance of providing nursing care for the elderly in Egypt. Thus increasing the number of nursing graduates who are knowledgeable and interested in caring for the elderly is one of the biggest challenges facing nurse educators. Nursing students can be prepared to care for the elderly can be a challenge. A previous study has found that nursing students often hold negative attitudes toward older people (Liuet et al., 2013). As well as nursing are presented with a unique challenge and opportunity of preparing nurses to provide a high quality of care to older adults across a variety of care settings. One of the important factors that affect the quality of care provided is nurses' attitude toward ageism, so study examining the attitudes of health care workers toward elderly individuals have been included in the literature recently. It is considered that the prejudices held by nurses towards the elderly are affected by many reasons such as their own values, perceptions, and beliefs (Eltantawy 2013).

Aim of the study:

The purpose of this study is to investigate the effect of intervention program on nursing student's attitudes regarding ageism.

Research hypothesis:

Attending the intervention program will be improving nursing student towards discrimination against the elderly. Design: One set pre-test, quasi-experimental design was used. Preparation: This study was conducted at the Faculty of Nursing at Mansoura University.

\section{Subject and methods}

\subsection{Subjects}

This study was performed using non-probabilistic, voluntary, and convenience sampling method. The study included the fourth year of nursing students who enrolled in the baccalaureate nursing program. A total of 110 fourth year students were enrolled during the academic year 2015/2016, with no other inclusion or exclusion criteria.

\subsection{Data collection tools}

\subsubsection{Tool i: self-administered questionnaire developed by researchers, including}

Social and demographic characteristics of students, where age, marital status, gender, family income level, etc. Questions related to previous knowledge about aging and care experiences describe the experience of living with older people, interest in care/issues of the elderly, communication with older people, or training and resources on this knowledge.

\subsubsection{Tool ii: kogan's attitude towards old people scale (KAOP)}

It consists of 26 items, thirteen statements are negatively framed and, thirteen statements are positively framed. The highest score in positively framed items indicates positive attitude and the highest score in negative framed items indicate negative attitude. Students were asked to respond on a 6 point Likert-types scale which ranging from "strongly disagree" to "strongly agree". An example of two paired statements in the KAOP scale is ("People grow wiser with the coming of old age" and "It is foolish to claim that wisdom comes with age"). The scale based on the tool originally developed by Kogan in the 1961 and modified for use by (Kiliç \& Adibelli, 2011). It has a good reliability, content and constructs validity, as well as convergent validity. The tools were rigorously revised by six experts in the nursing field for face and content validation. Their suggestions and comments were applied.

\subsubsection{Structured educational intervention with gerontology} content

The main objective of structured educational intervention with intervention program was to gain nursing students with efficient knowledge about geriatric nursing and change their negative attitudes in dealing with elderly one. The study intervention program was designed to be 15 sessions implemented in three phases, where first two sessions were for assessment, program sessions were 12 sessions and final session for evaluation. The finalized program was implemented in ten bi-weekly sessions. Each session took from 30 to 45 minutes.

The intervention program introduced to the fourth students in the faculty of nursing - Mansoura University in second semester 2016, the number of weeks 15 week. Teaching and learning methods used include lectures, group discussion, and role play through using scenario which applied within real students and simulated patient which conducted in home health care and clinical rotation in medical-surgical nursing departments at Mansoura hospital university and in a geriatric home in El-Esawy home - Mansoura city/ Dakahilia governorate. Students assessment methods include a clinical performance by using clinical performance and attitude rubric checklist, knowledge through the quiz, midterm and final exam At the end of this course students will acquire the essential knowledge, skills \& attitudes required to care for healthy \& sick elderly person in different clinical settings.

\subsection{Theoretical framework}

The study was conducted rooted in cognitive behavioral theory which assumes that human behavior is affected not only by events or situations themselves but also through interpretation of such events based on perception, thoughts, learning, and recognition.

\subsection{Study maneuver}

- An official letter was issued from the researcher to the dean of the faculty of the nursing Mansoura University to obtain his approval to carry out the study. The purpose of the study was discussed for the subjects. The subjects were was voluntary, all of the information collected was confidential, and anonymity was assured.

- The pilot study was conducted among 10 percent of the nursing students who consented as respondents to the questionnaire. This pilot run aimed to test the feasibility and comprehensiveness of the study design. After which, fundamental changes were done in the study design and the implementation process based on expert opinions on the initial results of the study.

- Data were collected using both tools at the same time for nursing students at the fourth academic year. The researcher met the students in the classroom, according to the time available in the lecture schedule (February 2016 to May 2016). The student took 30 to 45 minutes to complete the 
questionnaire papers. Researchers were available during data collection in the classroom. After completing the semester, another intervention has been assessed using the same forms and procedures as data collection.

\subsection{Statistical analysis of the data}

Data were fed to the computer and analyzed using SPSS software package version (20.0.) software. Further, a descriptive statistic was used and the inferences were expressed as means \pm SD (standard deviation). Frequency, percentage, and parametric variables were also assessed and determined using students test, while chi-squared analyses

\section{Results}

Table one reveals that the studied nursing students' age ranged between 19 and 22 years with a mean $20.5 \pm 2.5$ year. More than two thirds $(72.7 \%)$ of the students were females, only $10 \%$ were married. The minority $(9.1 \%)$ considered themselves in the high family income.

Table 2 demonstrates that more than half of students in the study sample $(56.2 \%)$ had an experience living with the elderly and (78.2\%) had an interest in elder care/issues, only small percentage of them $(8.2 \%)$ had to experience in caring for elderly and $42.8 \%$ of the students reported frequently communication with elderly persons, while $10.9 \%$ never communicate with them. Where as, only $36.4 \%$ of the studied subjects took training in geriatric care.

Table 3 explained the comparison between pre and post intervention in relation to negative items of an attitude scale. It can be observed that eight out of thirteen items in the negative attitude scale were decreased significantly after exposure to the geriatric course

Table 4 demonstrates the comparison between pre and post intervention, according to positive items of an attitude scale, It can be observed that three out of thirteen items in the positive attitude scale were increased significantly.

Table 5 indicates the comparison between pre and post intervention, according to the total score of attitude scale, it can be noticed that, a total score of negative items pre-intervention according to Min. - Max. was equal to 24.0 - 67.0 while post-intervention, it decreased to be equal to $(21.0-67.0)$. This decreasing in score reached statistically significant difference at $p$-value $<0.001$. Concerning the difference in total score of positive items in attitude scale pre and post-intervention, it was found that pre-score as described by Min. - Max was equal to $23.0-57.0$ while in postintervention, it increased to reach $23.0-68.0$. This increase in score reached statistically significant difference at $\mathrm{p}$-value $<0.001$.

Table 1: Sociodemographic Characteristics of the Studied Subjects $(\mathrm{N}=$

\begin{tabular}{lcl}
$110)$ & & \\
\hline Variable & \multicolumn{1}{c}{ Frequency } & Percent (\%) \\
\hline Mean age (years) & $20.5 \pm 2.5$ & \\
Sex : & & \\
Male & 30 & 27.3 \\
Female & 80 & 72.7 \\
Marital status : & & \\
Single & 99 & 90.0 \\
Married & 11 & 10.0 \\
No. of children: & $(\mathrm{n}=11)$ & \\
Non & 7 & 72.4 \\
$1-$ & 3 & 25.9 \\
$2+$ & 1 & 1.7 \\
Family income: & & \\
Not enough & 25 & 22.7 \\
Enough & 75 & 68.2 \\
High income & 10 & 9.1 \\
\hline
\end{tabular}

Table 2: Distribution of the Studied Subjects by Items Related to Elderly Care $(\mathrm{N}=110)$

\begin{tabular}{llc}
\hline Variable & Frequency & Percent (\%) \\
\hline Experience living with elderly: & & \\
Yes & 62 & 56.4 \\
No & 48 & 43.6 \\
Interest in elder carelissues: & & \\
Yes & 86 & 78.2 \\
No & 24 & 21.8 \\
Caring experience in the home: & & \\
Children & 73 & 66.4 \\
Adults & 28 & 25.4 \\
Elderly & 9 & 8.2 \\
Communication with elderly : & & \\
Frequent & 47 & 42.8 \\
Occasionally & 27 & 24.5 \\
Rare & 24 & 21.8 \\
Never & 12 & 10.9 \\
Training in geriatric care: & 40 & 36.4 \\
Yes & 70 & 63.6 \\
No & & \\
\hline
\end{tabular}

Table 3: Comparison between Pre and Post Intervention, According to Negatively Framed Items of Ageism Attitude Scale (N = 110)

\begin{tabular}{|c|c|c|c|}
\hline & Pre & Post & $\mathrm{P}$ \\
\hline $\begin{array}{l}\text { 1) It may be better if most seniors live in a } \\
\text { housing unit with people of their own age. }\end{array}$ & $\begin{array}{l}2.89 \pm \\
1.62\end{array}$ & $\begin{array}{l}2.82 \pm \\
1.54\end{array}$ & 0.616 \\
\hline $\begin{array}{l}\text { 3) There is something different from most } \\
\text { people. It's hard to know what makes them } \\
\text { sick. }\end{array}$ & $\begin{array}{l}3.18 \pm \\
1.22\end{array}$ & $\begin{array}{l}2.95 \pm \\
1.24\end{array}$ & $0.022 *$ \\
\hline $\begin{array}{l}\text { 5) Get the most elderly appointment in their } \\
\text { ways and are unable to change. }\end{array}$ & $\begin{array}{l}3.65 \pm \\
1.44\end{array}$ & $\begin{array}{l}3.42 \pm \\
1.45\end{array}$ & 0.185 \\
\hline $\begin{array}{l}\text { 7) Older people tend to leave their homes } \\
\text { becoming shabby and unattractive. }\end{array}$ & $\begin{array}{l}3.27 \pm \\
1.56\end{array}$ & $\begin{array}{l}3.04 \pm \\
1.50\end{array}$ & $0.002 *$ \\
\hline $\begin{array}{l}\text { 9) It is folly to claim that wisdom comes } \\
\text { with age. }\end{array}$ & $\begin{array}{l}3.38 \pm \\
1.62\end{array}$ & $\begin{array}{l}3.38 \pm \\
1.68\end{array}$ & 1.000 \\
\hline $\begin{array}{l}\text { 11) Older people make one feel sick and } \\
\text { comfortable. }\end{array}$ & $\begin{array}{l}3.35 \pm \\
1.35\end{array}$ & $\begin{array}{l}3.18 \pm \\
1.52\end{array}$ & $0.019 *$ \\
\hline $\begin{array}{l}\text { 13) Holds older people through their insist- } \\
\text { ence on talking "about the old days". }\end{array}$ & $\begin{array}{l}3.35 \pm \\
1.43\end{array}$ & $\begin{array}{l}3.05 \pm \\
1.53\end{array}$ & $0.002 *$ \\
\hline $\begin{array}{l}\text { 15) In order to maintain a nice residential } \\
\text { neighborhood, it would be better if many } \\
\text { older people did not live there. }\end{array}$ & $\begin{array}{l}3.0 \pm \\
1.64\end{array}$ & $\begin{array}{l}2.91 \pm \\
1.66\end{array}$ & 0.133 \\
\hline $\begin{array}{l}\text { 17) There are few exceptions, but in general, } \\
\text { older people are pretty much alike. }\end{array}$ & $\begin{array}{l}3.69 \pm \\
1.17\end{array}$ & $\begin{array}{l}3.33 \pm \\
1.32\end{array}$ & $0.002 *$ \\
\hline $\begin{array}{l}\text { 19) Older people should be more concerned } \\
\text { with their personal appearance. They are } \\
\text { very untidy. }\end{array}$ & $\begin{array}{l}2.98 \pm \\
1.21\end{array}$ & $\begin{array}{l}2.67 \pm \\
1.41\end{array}$ & $0.008^{*}$ \\
\hline $\begin{array}{l}\text { 21) Most of the elderly are agitated, surly, } \\
\text { and unpleasant. }\end{array}$ & $\begin{array}{l}2.96 \pm \\
1.29\end{array}$ & $\begin{array}{l}2.80 \pm \\
1.13\end{array}$ & 0.290 \\
\hline $\begin{array}{l}\text { 23) Most older people constantly complain } \\
\text { about the behavior of a young generation. }\end{array}$ & $\begin{array}{l}4.02 \pm \\
1.27\end{array}$ & $\begin{array}{l}3.64 \pm \\
1.44\end{array}$ & $0.001 *$ \\
\hline $\begin{array}{l}\text { 25) More than the elderly make excessive } \\
\text { demands for love and reassurance from }\end{array}$ & $\begin{array}{l}3.87 \pm \\
1.48\end{array}$ & $\begin{array}{l}3.65 \pm \\
1.62\end{array}$ & $0.004 *$ \\
\hline
\end{tabular}
anyone else.

p: p-value for Paired t-test.

*: Statistically significant at $\mathrm{p} \leq 0.05$.

Table 4: Comparison between Pre and Post Intervention, According to Positive Items of Ageism Attitude Scale ( $\mathrm{N}=110)$

\begin{tabular}{|c|c|c|c|}
\hline & Pre & Post & $\mathrm{p}$ \\
\hline $\begin{array}{l}\text { 2) It may be better if most people live } \\
\text { in a housing unit with young people. }\end{array}$ & $\begin{array}{l}2.84 \pm \\
1.41\end{array}$ & $\begin{array}{l}2.93 \pm \\
1.49\end{array}$ & 0.505 \\
\hline $\begin{array}{l}\text { 4) Older people are actually no dif- } \\
\text { ferent from anyone else. They are } \\
\text { easy to understand as younger. }\end{array}$ & $\begin{array}{l}2.51 \pm \\
1.30\end{array}$ & $\begin{array}{l}2.87 \pm \\
1.58\end{array}$ & $0.007 *$ \\
\hline $\begin{array}{l}\text { 6) Older people are able to make new } \\
\text { adjustments when the situation re- } \\
\text { quires it. }\end{array}$ & $\begin{array}{l}3.05 \pm \\
1.34\end{array}$ & $\begin{array}{l}3.35 \pm \\
1.32\end{array}$ & 0.062 \\
\hline $\begin{array}{l}\text { 8) Most older people are generally } \\
\text { dependable to keep the environment } \\
\text { clean, inside. }\end{array}$ & $\begin{array}{l}3.38 \pm \\
1.16\end{array}$ & $\begin{array}{l}3.56 \pm \\
1.20\end{array}$ & 0.086 \\
\hline $\begin{array}{l}\text { 10) People grew wiser with coming } \\
\text { to life. }\end{array}$ & $\begin{array}{l}3.67 \pm \\
1.31\end{array}$ & $\begin{array}{l}3.73 \pm \\
1.38\end{array}$ & 0.672 \\
\hline $\begin{array}{l}\text { 12) Most of the seniors are very } \\
\text { relaxing to be with. }\end{array}$ & $\begin{array}{l}3.25 \pm \\
1.22\end{array}$ & $\begin{array}{l}3.49 \pm \\
1.33\end{array}$ & 0.096 \\
\hline $\begin{array}{l}\text { 14) One of the most interesting and } \\
\text { entertaining features of older people }\end{array}$ & $\begin{array}{l}3.85 \pm \\
1.46 \\
\end{array}$ & $\begin{array}{l}4.02 \pm \\
1.55 \\
\end{array}$ & 0.172 \\
\hline
\end{tabular}


is their calculations of their previous experiences.

16) You can count on finding a nice residential neighborhood when there is a sizeable number of old people

living in it

18) It is clear that most older people are very different from each other.

20) More than the elderly looks very clean and stylish in personal appearance.

22) More than the elderly are cheerful, acceptable, and good-natured.

24) One rarely hears older people complaining about the behavior of a younger generation.

26) Most older people need more love and reassurance than anyone else.

p: p-value for Paired t-test.

*: Statistically significant at $\mathrm{p} \leq 0.05$

Table 5: Comparison between Pre and Post Intervention, According to Score of Attitude Scale $(\mathrm{N}=110)$

\begin{tabular}{llll}
\hline & Pre & Post & $\mathrm{p}$ \\
\hline Total score of negative items & & & \\
Min. - Max. & $24.0-67.0$ & $21.0-67.0$ & $<0.001^{*}$ \\
Mean \pm SD & $43.60 \pm 8.08$ & $40.84 \pm 8.67$ & \\
Total score of positive items & & & \\
Min. - Max. & $23.0-57.0$ & $23.0-68.0$ & $<0.001^{*}$ \\
Mean \pm SD & $41.55 \pm 7.18$ & $44.15 \pm 8.73$ & \\
\hline
\end{tabular}

The p-value for Paired t-test.

*: Statistically significant at $\mathrm{p} \leq 0.05$.

\section{Discussion}

The present study results point that educational intervention with gerontological nursing content decreases students' negative attitude toward older adults. This result is certainly attributed to the geriatric educational program which provided these students with needed knowledge through planning to incorporate a variety of data that manipulate positive attitude. So, equipping students with the basic knowledge required through creative learning methods during gerontological coursework will encourage nursing students to experience and evaluate their own personal aging and biases Like using of experiential methods such as film, scenario, role play, group discussion, watching the related video and speak about real life situations and guided fantasy were very helpful in the students' attitudinal assessment process and reinforcing discussion. This result is consistent with the theory of cognitive coherence, which examines the relationship between attitudes and beliefs. An unstable situation occurs when an individual's attitudes towards an object and knowledge about this topic are inconsistent. Try persuasive communication to change the emotional element system position by changing the cognitive component of the position. In other words, providing the individual with new information that changes the cognitive component of the attitude will tend to cause the individual to change public attitudes towards the object. In theory, nurses with higher education increased knowledge of gerontology and gerontology should offer more positive attitudes because they better understand older people and identify their needs than those without any professional knowledge in this area (Russell et al., 2003). In congruence with this, Lee et al., (2015) in a comparative study between United States and Korean nursing students demonstrated a significant effect of gerontology content on nursing students who showing significantly lower negative attitudes and negative feelings toward older adults, lower anti-age bias, and improvement in pro-age bias over time as compared to non-nursing students. This might be explained by the fact that nursing students consider/learn more overall aging phenomena in physical, psychological, spiritual and social aspects.

In agreement with this finding, Oyetunde et al., (2013) revealed significant positive effects of nursing education on gerontology and training on the attitude of nursing students towards older peo- ple. Paradoxically, a previous study by Holroyd et al. (2009) indicates that educational experiences have not changed nursing attitudes towards aging students. These contradictory results may be related to curriculum content, which has been low to moderate in relation to student attitudes toward aging and seniors. Moreover, a study conducted in Turkey by Uysal et al., (2014) revealed that most nursing students announced that they wanted to work with old patients after graduation for the elderly needed more physical and psychological support that affects the quality of old care.

Regarding the comparison between nursing program stages before and after aging in this study, according to the positive items on the scale and position, it can be observed that three out of thirteen elements have been increased in the range of a significantly positive attitude, which is called (most older people are really no different from Anyone else; they're easy to understand as younger, and most older people seem very clean and stylish in their personal appearance, and most seniors are cheerful, acceptable, and very self-effacing)..This discovery adds to evidence that supports clinical placement and approaches that focus on specific phenomena to older populations promoting positive attitudes of nursing students towards older people. In the same line, a study conducted in Saudi Arabia by Alamri and Xiao (2017) showed that the above findings support the theory that education on the growth process influences the old position, and the pool of constructive experiences at the time of clinical training enhances the outcome

On the contrary, Topaz and Duron (2013) in Israel concluded that although "education has been identified as a highly interrelated factor with nurses attitudes towards aging in the bi-variable analysis, its effect have disappeared when other factors are determined." This conclusion is not surprising in the absence of The existence of age-related and age-related content in any nursing education programs in Israel.

In line with this, Wurtele and Maruyama (2013) and King et al., (2014) suggest that the aging path seems to have a positive impact on the views of older students. The students helped, of course, dispel the myths they had about cared for the elderly and made the course of them appreciate how complex care for the elderly could be. Therefore, of course, aging has the inherent value of improving the views of students about caring for the elderly, but it may not be the only driving force to change the attitude. In the same vein, Sheikh et al. (2013) concluded in a study in the United Arab Emirates that improving training and exposure to older persons may trigger aging. Improving the situation may have a positive effect on the situation, encouraging more individuals to enter the field and in turn, benefit the elderly patients in all institutions.

In identical with the above results, study in Ohio. (2016) The United States revealed that other Kenyans understand that student attitudes can help us to promote positive attitudes and reduce the fear of older suffering and death as an obstacle facing students working with older people. In the same line, Powers et al., (2013) recommended the increasing need for motivated nurses to provide care for seniors with a positive attitude. Kimzey et al., (2016) also suggest that experimental learning in the form of clinical placements increases knowledge and improves attitudes about Alzheimer's disease compared with the Internet unit and any specific dementia interference. Regarding the comparison between nursing program stages before and after aging in this study, according to the negative items on the scale and position, it can be noted that three out of eight items in the passive position range decreased significantly, which is called (there is something different from most people, it is difficult to Find out what makes them sick and most seniors tend to leave their homes becoming shabby and unattractive, most older people make one feel sick and comfortable, and carry the majority of other seniors by insisting on talking "about the old days. There are a few exceptions, older people are pretty alike many, older people should be more concerned with their personal appearance, they are very uncluttered, and most older people are constantly complaining about the behavior of a younger generation, and most older people make excessive demands for love and reassurance than anyone else). This finding designates a favorable disposition towards older adults. This find- 
ing is inconsistent with Kydd et al., (2014) in Scotland, who recommended that it is necessary to promote a positive attitude and to present advantages of working with the aging people, which can be achieved with the help of teachers and all National Health Service employees. It is highly worrying that with the still growing number of the elderly, care and social interest taken in them is on the decrease.

Meanwhile, Hovey et al., (2017) and Strugala et al., (2016) in Poland stated that nursing students' positive attitude towards the elderly is a prerequisite for better care to the elderly and it is closely correlated with the understanding, affection, respecting and empathy with older adults. In agreement with this, a study in China Kwan \& Law (2014) examined the factors which may pitiful a medical student's choice of gerontology as a career. This incorporated in a survey of attitude towards the elderly and understanding of aging among first and third-year Chinese undergraduates.

In this respect, Setchoduk et al., (2015) \& Sawaengdee et al., (2017) in a two studies in Thailand explored that nursing students attitude toward older adults and incorporating more factors that may influence this by using Modified Kogan's Old People Scale (Modified KOPS), they found that age, religion and year of study were the significant factors influencing nursing students' attitude toward older adults. Furthermore, the Modified KOPS statement analysis found that gender, nationality, and social interaction with older adult including having older adult care experiences, living with older adult relatives, and being in a close relationship with an older adult in the family were significant factors influencing nursing student's attitudes toward older adults.

Furthermore, Cheong et.al (2009) who conducted a cross-sectional study evaluating the attitude toward the elderly using Kogan's Attitudes Toward Old People Scale (KAOP) in Singapore, stated that it is important that medical students possess the positive attitude toward the elderly and not have an against attitude. This is because they will be caring for an increasing proportion of elderly patients. Also, their result showed that the majority of first and third-year medical students $(98.2 \%, 99.2 \%$, respectively) had positive attitudes towards elderly people (KAOP score above 102). KAOP scores were not the significantly different regardless level of seniority, gender, race, household income, or having a doctor parent. Finally, they recommended that medical curriculum should continue to have an increasing geriatric component in view of the increasing numbers of older persons that they will be cared for due to the aging population.

Consequently, (Liu et al., 2014) stated that among undergraduates, $71.3 \%$ did not acquire significant knowledge about the elderly (mean KAOP score $139.5 \pm 16.0$ ); and had a mean score of knowledge of aging $(12.2 \pm 2.7)$. The majority of first and thirdyear students had a positive attitude (KAOP > 102). The KAOP score among first-year students was higher than that among third years $(\mathrm{P}<0.01)$. In the same line, the study of Abreu and Caldevilla (2015) in Portugal postulated that students with an interest in problems of the elderly had significantly higher scores and were more willing to consider careers in gerontology than students without an interest in the elderly $(\mathrm{P}<0.01)$.

\section{Conclusion}

The results of the study indicate the effectiveness of the intervention of the university nursing program in the negative attitude towards elder care.

\section{Recommendations}

Based on the findings of the study, the following recommendations were proposed:

- Further research can be conducted on a larger sample at different universities in Egypt.

- Follow-up evaluation of subsequent tests conducted in the sixth and ninth month after the intervention to verify reten- tion of knowledge of nursing students and apply them to a positive attitude.

- Spread this nursing program to other nursing students in all disciplines in Egypt in order to emphasize the results and improve educational intervention.

- Nurses' education specialists promote reproductive content in nursing curricula and provide culturally designed nursing education to reduce the distinction between professional nurses.

\section{Acknowledgment}

Thanks to all the nursing students at Mansoura University who accepted to participate in this study.

\section{References}

[1] Abreu M., Caldevilla N. (2015): Attitudes toward aging in Portuguese nursing students. Procedia - Social and Behavioral Sciences 171. 961 -967 Available online at www.sciencedirect.com Science Direct 1877-0428 (C) 2015 (http://creativecommons.org/licenses/bync-nd/4.0/). ICEEPSY https://doi.org/10.1016/j.sbspro.2015.01.215.

[2] Alamri, B. H. and Xiao L. D., (2017): Health professionals' knowledge and attitudes toward older people in primary care in Saudi Arabia. Saudi Med J; 38(3): 229-236. https://doi.org/10.15537/smj.2017.3.19293.

[3] Bravo R. (2017): College students' attitudes toward older workers Electronic Theses, Projects, and Dissertations. 442. http://scholarworks.lib.csusb.edu/etd/442.

[4] Central Agency for Public Mobilization Statistics (2011): The Statistical Year Book (June 2010) Elderly in Egypt. 2010. Available: http://www.global aging.org. Retrieved 13 September 2012.

[5] Cheong, S. K., Wong, T. Y., \& Koh, G. C. H. (2009): Attitudes towards the elderly among Singapore medical students. Annals of the Academy of Medicine Singapore, 38(10), 857-861.

[6] Coffey A, Whitehead N. (2015): Healthcare assistants' attitudes towards older people and their knowledge about aging. Nursing Older People; 27: 24-30. https://doi.org/10.7748/nop.27.1.24.e665.

[7] Demir G., Bicer S., Bulucu-Böyüksoy G.D., Özen B., (2016): Attitudes of Nursing Students about Ageism and the Related Factors International Journal of Caring Sciences September - December Volume 9 | Issue 3| Page 901. www.international journal of caring sciences.org.

[8] Eltantawy S.H. (2013): Relation between Nursing Students' Knowledge of Aging and Attitude towards Elderly People and Their Will and Intent to Work with the Elderly. Journal of Education and Practice www.iiste.org ISSN 2222-1735 (Paper) ISSN 2222-288X (Online) Vol.4, No.27.

[9] Holroyd A, Dahlke S, \& Fehr C. (2009): Attitudes toward aging: implications for a caring profession. J Nurs Educ; 48(7): 374-80. https://doi.org/10.3928/01484834-20090615-04.

[10] Hovey, S., Dyck, M. J., Reese, C., \& Kim, M. J. (2017): Nursing students' attitudes toward persons who are aged: An integrative review. Nurse Education Today, 49, 145-152.Journal of Abnormal and Social Psychology 62(3), 616-622.

[11] Kiliç D, Adibelli D (2011): The validity and reliability of Kogan's attitude towards old people scale in the Turkish society. This study was presented as a poster announcement at the Turkish Geriatrics 2010 National Elderly Health Congress, held between the $1^{\text {st }}$ and $4^{\text {th }}$ April 2010. Openly accessible at http://www.scirp.org/journal/HEALTH/.

[12] Kimzey M., Mastel-Smith B. \& Alfred D. (2016): The impact of educational experiences on nursing students' knowledge and attitudes toward people with Alzheimer's disease: A mixed method study. Nurse Educ Today. 2016 Nov; 46:57-63. https://doi.org/10.1016/j.nedt.2016.08.031.

[13] King B.J., Roberts T.J., \& Bowers B.J., (2014): Nursing Student Attitudes Toward and Preferences for Working with Older Adults. Gerontol. Geriatr. $\quad$ Educ.; $34(3)$ : 272-291. https://doi.org/10.1080/02701960.2012.718012.

[14] Kinney, J. M., Yamashita, T., \& Brown, J. S. (2016): Measuring positive attitudes toward persons with dementia: A validation of the Allophilia scale. Ohio University. United States Dementia.doi: 1471301216633247. 
[15] Kogan, N. (1961): Attitudes toward old people: The development of a scale and an examination of correlates. Journal of Abnorma and Social Psychology, 62, 44-54. https://doi.org/10.1037/h0048053.

[16] Kwan, A. \& Law, B. (2014): Attitudes of student/pupil nurse toward the aged in Hong Kong: implications for nursing education. Hong Kong Journal of Gerontology, 21 (1): 45-51.

[17] Kydd A, Touhy T, Newman D, Fagerberg I, Engstrom G (2014): Attitudes towards caring for older people in Scotland, Sweden, and the United States. Nurs Older People 26: 33-40. https://doi.org/10.7748/nop2014.02.26.2.33.e547.

[18] Lee Y. Sh, Shin S. H., Greiner Ph. A. (2015): Can education change attitudes toward aging? A quasi-experimental design with a comparison group in the United States and Korea. Journal of Nursing Education and Practice. Vol. 5, No. 9. www.sciedu.ca/jnep original research. ISSN 1925-4040 E-ISSN 1925-4059. Published by Sciedu Press.

[19] Libertini G, Ferrara N. (2016): Aging of perennial cells and organ parts according to the programmed aging paradigm. Age (Dordr.); 38:1-13. https://doi.org/10.1007/s11357-016-9895-0.

[20] Liu Y, Norman IJ, While AE. (2013): Nurses' attitudes towards older people: a systematic review. International Journal of Nursing Studies.50 (9):1271-1282. https://doi.org/10.1016/j.ijnurstu.2012.11.021.

[21] Liu YE, Norman IJ, While AE. (2015): Nurses' attitudes towards older people and working with older patients: an explanatory model. J Nurs Manag; 23: 965-973. https://doi.org/10.1111/jonm.12242.

[22] Liu, Z., Pu, L., Wang, H., \& Hu, X. (2014): Survey of attitude towards an understanding of the elderly amongst Chinese undergraduate medical students. Asian Biomedicine, 8 (5), 615-622. https://doi.org/10.5372/1905-7415.0805.335.

[23] Meiner SE (2015): Overview of gerontologic nursing. In: Meiner SE (ed.). Gerontologic nursing, (5thedn). Elsevier Mosby, Maryland Heights, MS, USA.

[24] Oyetunde, M., Ojo, O. \& Ojewale, L. (2013): Nurses' attitude towards the care of the elderly. Implications for gerontological nursing training. Journal of Nursing Education and Practice, 3(7):150158. https://doi.org/10.5430/jnep.v3n7p150.

[25] Powers, M., Gray, M., \& Garver, K. (2013). Attitudes toward older adults: Results from a fitness-based intergenerational learning experience. Journal of Intergenerational Relationships, 11(1), 50-61. https://doi.org/10.1080/15350770.2013.755067.

[26] Russell H. Fazio and Michael A. Olson (2003): Implicit measures in social cognition research: their meaning and use. Department of Psychology, Ohio State University, Columbus, Ohio, 43210-1222, e-mail: Fazio@psy.ohio-state.edu Annu. Rev. Psychol. 2003. 54:297-327 https://doi.org/10.1146/annurev.psych.54.101601.145225.

[27] Sawaengdee K., Pudpong N., Wisaijohn Th., Suphanchaimat R., Putthasri W., Lagarde M., and Blaauw D. (2017): Factors associated with the choice of public health service among nursing students in Thailand. BMC Nurs. 2017; 16: 8 . https://doi.org/10.1186/s12912-017-0202-x.

[28] Schlein L. (2016): Study: Negative Attitudes Toward Older People Shorten Their Lives. SCIENCE \& HEALTH. 29, 1:30.

[29] Setchoduk, K. (2015): Attitude toward older adult among nursing students in private university, Thailand.J Pup. Health Dev., 13(12):3-6.

[30] Sheikh, R., Mathew E., Rafique, E., Suraweera, R., Khan, H. \& Sreedharan, J. (2013): Attitude of medical students toward old people in Ajman, United Arab Emirates. Asian Journal of Gerontology\& Geriatric, 8:1-5

[31] Strugala M, Talarska D, Wysocki J (2016): Attitudes Towards the Elderly among Nursing Students in Poland - Initial Findings. J Gerontol Geriatr Res 5:279. https://doi.org/10.4172/21677182.1000279

[32] Swift H. J., Abrams D., Lamont R. A., Drury L. (2017): The Risks of Ageism Model: How Ageism and Negative Attitudes toward Age Can Be a Barrier to Active Aging. Social Issues and Policy Review, Vol. 11, No. 1, pp. 195-231. https://doi.org/10.1111/sipr.12031.

[33] Topaz, M., Doron, I., (2013): "Nurses' Attitudes toward Older Patients in Acute Care in Israel" OJIN: The Online Journal of Issues in Nursing Vol. 18 No. 2.

[34] Uysal, G., Derya-Beydag, K., Sensoy, F., Ozaydin, N. \& Kıyak, M. (2014): Attitudes of students who receive health education in a foundation university regarding age discrimination. Social and Behavioral Sciences, $7, \quad 430-434$ https://doi.org/10.1016/j.sbspro.2014.09.226.
[35] World Health Organization (2016): 'Discrimination and negative attitudes about aging are bad for your health', Media Centre, WHO, $29 \quad$ September 2016, http://www.who.int/mediacentre/news/releases/2016/discrimination -ageing-youth/en/.

[36] Wurtele SK, Maruyama L (2013): Changing students' stereotypes of older adults. Teach Psychol 40: 59-61. Wurtele SK, Maruyama L (2013) Changing students' stereotypes of older adults. Teach Psychol 40: 59-61. https://doi.org/10.1177/0098628312465867. 